\title{
Role of Professional Women in Conflict Resolution and Peace Building in Niger Delta Region of Nigeria
}

\author{
Iruloh, Betty- Ruth N. ${ }^{1}$, Uche, Chineze M. ${ }^{1}$ \\ ${ }^{1} \mathrm{PhD}$, Faculty of Education, University of Port Harcourt, Nigeria \\ Correspondence: Uche, Chineze M., PhD, Faculty of Education, University of Port Harcourt, Nigeria.
}

Received: January 11, 2017

Accepted: February 24, 2017

Available online: March 27, 2017

doi:10.11114/ijsss.v5i4.2306

URL: https://doi.org/10.11114/ijsss.v5i4.2306

\begin{abstract}
Oil and gas activities in Southern part of Nigeria have exposed the region to environmental degradation and social vices. This problem has caused conflicts among stakeholders (government, community, companies, institutions, individuals), which has led to community clashes. These conflicts have resulted to the loss of lives and properties. They are also responsible for youth restiveness, low level of women empowerment and lack of peaceful coexistence in the region. This makes the promotion of understanding and dialogue to be a prime issue in the management of conflict, community peace and security. Professional women belong to professional bodies that spread into all works of life; academia, government, industry, legal institution, health sector, financial institutions, NGOs, security sector. This paper discussed issues on causes of conflict in Niger Delta, what roles should professional women play in attaining peace, global examples of professional women in conflict resolution, role of professional women in Niger Delta, way in which women engage in conflict resolution and challenges women face in conflict resolution and peace building. The paper concluded that time has come for everybody to be aware of gender equality and involvement in conflict resolution and peace building. Professional women need to intensify effort in achieving this.
\end{abstract}

Keywords: professional women, women in peace building, conflict resolution, Niger delta region

\section{Introduction}

Conflicts are part of our human existence. They arise when individuals, groups and entities pursue their own different interests, goals and aspirations. Faleti (n.d) defines conflict as 'opposition among social entities directed against one another. ${ }^{1}$ When groups disagree and believe their goals are not compatible, conflict has set in. Cooperation is the opposite of conflict. Peace is also an opposite of conflict. Anikpo ${ }^{2}$ has identified an intriguing paradox when he warned that development will not take place unless the conflict is resolved. Conflict can also be seen as 'a tussle over values norms, status, power and resources, a struggle in which the aims of opponents are to neutralize, injure or eliminate rivals, ${ }^{3[3]}$ In this case those who engage in this struggle will insist that the conflict will not end unless their demands are met.

\subsection{Conflict as a Necessary Evil}

From the definitions and implications of what conflict stands for some people, conflict is not totally bad but what is wrong is violence and its results from poor handling of perceived grievances and dissatisfaction with certain outcomes by persons or groups in the society. At the level of entering-group conflict, opponents believe strongly in avenging any injustice done to them.

However, conflict is positive when it serves as a critical mechanism by which the goals and aspirations of individuals

\footnotetext{
${ }^{1}$ Faleti S.A. (n.d) Theories of Social Conflicts in Shedrack, G.B. Introduction to Peace and Conflicts Studies in West Africa. Ibadan: Spectrum Books. 2006.

${ }^{2}$ Anikpo, M.O.C. The Dynamics of Socio-cultural change in Nigeria's oil producing communities: The case of Izombe Energy and Social Development in Nigeria. Onyige. P.U. Longman. 1996

${ }^{3}$ Anikpo, M.O.C. Conflict and Development in the Niger Delta: Sociological Perspective. Enugu: ABIC BOOKS. 2015.
} 
and groups are understood and articulated. It is a fulcrum for defining idea-initiative results to human challenges. ${ }^{4}$

\subsection{Position of the Niger Delta Region in Nigeria}

Niger Delta Region contains the nine oil bearing States in the South- South geopolitical zone in Nigeria. These states are also classified as the minority ethnic and sub-ethnic coastal groups based on the demographic and political factors. In 1956 crude oil was found to exist in commercial quantity at Olobiri, Bayelsa State and other parts of Niger Delta region. Yet the demographic and political powers of the majority groups in the country perpetrated the marginalization of the minority areas from infrastructural development and the national political leadership (Anikpo 2015). Kemedi, Alagoa and Leton in 2015 described the oil region as the engine room nation's oil production, as represented by John Keane in 1996 named the "zone of violence". He posited the economic and political marginalization has resulted to militancy and communal crisis. This has also made the people from these areas to vow that conflict will not end in the region unless the region is developed to their taste.

\subsection{Relevance of Professional Women in Conflict Resolution}

The most critical commitment for stakeholders of which professional women are part, is to take every preventive measure to prevent conflicts from becoming violent or destructive. When conflict occurs they also play role in resolving it and help in building mechanism that will establish a permanent peace. Women and children are mostly affected when conflict occurs in an area. Thus involving women in solving conflict and building peace in Niger Delta is logical. Professional women are working class women or business women who by virtue of their academic and technical qualification belong to different professional bodies. These professional bodies spread into all works of life; academia, government, industry, legal institution, health sector, financial institutions, NGOs, security sector. Therefore the professional women are in position to help to fight the course of their fellow women who may not be as educated or privileged as they are. The aim of this work was to examine the role of professional women in conflict resolution and peace initiative in south-south of Nigeria. Although this paper addressed the causes of conflict in Niger Delta, its main thrust was on the part professional women play in conflict resolution and peace initiative in skirmish settlement and community development; how they play their role in conflict resolution and challenges they face in playing the role, such as career, vocational, marital and religious challenges.

\subsection{Causes of Conflict in Niger Delta}

There are different kinds of conflict that occur in the Niger Delta. Some of these conflicts affect the whole region while others are specific to particular communities. Generally conflicts in Niger Delta are caused by the following:

1. Political agitation for autonomy and resource control

2. Demand for compensation from oil companies

3. The crisis of Militant uprising (that led to 2009 Amnesty Program)

4. Chieftaincy tussle

5. Government insincerity in resource sharing

6. Cult activities

7. Unnecessary barrier adjustment

\subsection{The Importance of Conflict Management and Resolution}

Conflict may be defined as a tussle or fight between people with different necessities, aims, opinions, values, or morals, philosophies, etc. Conflict most often is unavoidable and unpredictable. However, the outcomes of conflict are not known. Conflict might intensify and result to ungainful output, or may lead to gainful result. Therefore, studying to control conflict is an important factor for a team high-performance. Although very few people look for conflict, more often than not, conflict results because of miscommunication between people with regard to their needs, ideas, beliefs, goals, or values. Conflict management is the principle that all conflicts cannot necessarily be resolved, but learning how to manage conflicts can decrease the odds of nonproductive escalation. Conflict management involves acquiring skills related to conflict resolution, self-awareness about conflict modes, conflict communication skills, and forming a solid structure on management of conflict in the society. ${ }^{5}$

\footnotetext{
${ }^{4}$ The Albert, I.O. Introduction to Third Party intervention in Community Conflicts, Ibadan, Nigeria: PETRAF and John Archers (Pub.). 2001, 3.

5 The Foundation Coalition: Understanding Conflict and Conflict Management. Retrieved from http://www.foundationcoalition.org/terms_on January 8th, 2015.
} 


\section{Role of Professional Women in Conflict Resolution and Peace Building}

Women also derive authority, by implication, from the government to involve in peace education. This power arises from her civic obligations. Women are found in almost all offices, organizations and in fact all places. They join in planning, advising, organizing and solving problems in their respective places of work and business. As direct staff and participants who work for the common good of all, women have every opportunity to panel beat peace motives into their suggestions and submissions. Neglecting such strong awareness of fostering peace would be very pitiable indeed. More so, there is a sense of commitment women exhibit in peace building especially when they know it is likely to affect them and their family. Women often show keen interest as they are involved in any type of loss whether as widow, childless, homeless etc. Thus women, especially, professional women are relevant in settling issues on conflict in the community. Career women, often find it easy to perpetrate peace through our colleagues in the office.

In this era of globalization, the government of the day considers global implications of actions and/or inactions seriously. By encouraging women to publicly involve in peace education, the government would have constituted another formal elevation of women from their culturally ordained kitchen roles and thrust them further into public institutional settings outside the home. That way, the government signals to the citizens and to the world at large, their commitment to the integrity of their political structures and protocols. It would thus be a clear indication that women are consistently being moved into key administrative and decision making positions alongside men in the formal state apparatus and in the multinational private sector. Peace is both a political, individual and Government Issue. Government, by involving women in peace education, would be building consciously, and conspicuously, stronger humanitarian political, institutions. ${ }^{6}$ Women are very good at managing conflicts. This is why they survive in inter tribal marriages and inter religious marriages. Even the acronym for woman attests to this:

W-Wife (wonderful instrument for enjoyment);

O- Organizer;

M- Manager

A-Administrator and

N- Nurse.

Locally, women do not acknowledge their role on peace building initiatives because women are seen as family managers in providing household essential services. ${ }^{7}$ Women in this era naturally operate as mediators between husbands and children, maiden homes and matrimonial homes. Thus, while they organize and manage to avoid conflicts, they equally administer justice to reduce conflict and finally nurse victims of conflicts in crisis situations.

Efforts have variously been made by women to discourage the sustenance of conflicts in the world. Studies have has also shown that women's involvement in peace planning has helped to produce long term successes because women have been known to adopt more inclusive approaches towards security. Women participation in conflict resolution tackles key on social and economic matters that might otherwise be overlooked, yet such exerts a lot on peace initiatives. ${ }^{8}$ It is worthy of note, that women advocate for peace in polygamous homes when most often, men politicize marriage. Niger Delta is not left out in such homes.

In the proliferation of churches today, women find ways of reducing to the barest minimum, conflicts that are likely to arise from the variation of ideas. Thus, while the Counseling Psychologist approaches it from the inner conflicts perspective that manifest in outer conflicts, the implications for counseling and human capacity development are being highlighted.

\subsection{Global Examples of Professional Women Involvement in Peace Building}

In December 2002, women in Sri Lanka were active in drawing the agenda for the peace process. This led to the attention of gender characteristics of aftermath clashes in settlement of conflicts. However, this was hampered by the parity of women representative in political arena, education sittings, gender biases and fierceness against women.

\footnotetext{
${ }^{6}$ Bakky, N.A. Women in peace Education: IOSR Journal of Research \& Method in Education (IOSR-JRME) e-ISSN: 2320-737X (4), 3 (May-Jun. 2014), Pp01-08 www.iosrjournals.org

${ }^{7}$ Internal Alert. Women, Violent Conflict and Peace Building: Global Perspective. International Conference Report. London. 1999.

${ }^{8}$ Boulden, J. Dealing with Conflicts in Africa: The United Nations and Regional Organizations. Basingstoke: Macmillan Publishers. 2004.
} 
In Somalia in 2000, 92 women delegates to the Somali National Peace Conference enshrined themselves as the 6th clan for peace. Despite the resistance they suffered from the men, they still helped to draw- up a national charter that involved 25 seats for women out of the 245 member transitional National Assembly. ${ }^{9}$

In 1996, 200 women organization for representative in Northern Ireland Women's coalition, which is the first women folk dominated in political party. This movement entails members from both catholic communities and protestant and they operated as a cross community party to promote civil, human and workerse ${ }^{\text {ee }}$ rights. ${ }^{10}$ The alliance was eventually credited by George Mitchell, the US Senator who arbitrated the Northern Ireland peace resolutions with helping to achieve an agreement in those negotiations ${ }^{11}$.

The need for peace building for peace building cannot be undermined in this globalized society. Therefore peace initiatives should include policies that will address specific women health and economic needs ${ }^{12}$ because women actively participate on various roles in conflict and have different perceptions from men and share common vulnerabilities equally. Again the neglect of health and economic well-being of women during peace process are undermined and women bear a lot of burden and care for survivors.

To incorporate women issues into global affairs, the United Nations in October of 2000 took the giant approach in identifying the significant role women play in averting and settling conflict with the passage of the resolution (S/RES/1325). This bill revealed the relevance of women's involvement in all efforts to maintain and promote of peace and security in the world. However, the exclusion of women from participating in peace process contravenes their rights and this bill in emphasizing the importance to expand the number of women participation in decision- making with respect to conflict management for peace sustainable.

The effect of this condition and agreement was further strengthened by the creation of national action plans by 24 nations including Nigeria. This confirms Nigerian government is supporting women involvement conflict issues using Gender Based Violence (GBV). Furthermore, Resolution 1325 has also been supported the argument adopted by the Security Council in 2008 and 2009 which focus on five goals:

- $\quad$ Resolution 1325 (2000) Strengthening women's participation in decision making

- Resolution 1889 (2009) Complements 1325, by "calling for the establishment of global indicators to measure progress on its implementations.

- $\quad$ Resolution 1820 (2008) calls for an end to sexual violence and impunity.

- Resolution 1888 (2009) focuses on strengthening leadership, expertise and other institutional capacities within the United Nations and in member states to help put an end to conflict related sexual violence.

- Resolution 1960 empowers the Secretary General to identify and take action against countries suspected of committing patterns of sexual violence and calls for the establishment of monitoring, analysis, and reporting arrangements specifically to conflict-related sexual violence.

The five goals are meant to drive women's work on peace and security issues. It was noted that men do not seem to understand or come to terms with the impact which women have made not only in diplomacy, but in providing holistic solutions to resolving conflict.

Thus, the argument has been that women's views and perspectives play an integral part in influencing the processes of peace. However, despite recent efforts to improve the representation of women in international operations and peace processes, Nigerian women's voices are absent from high level discussions on peace and security. Furthermore, women's contributions to peace building, which are culturally specific and often grass-roots based continue to be

\footnotetext{
${ }^{9}$ Rhen, E. and Sirleaf, J. Women, War and Peace: The Independent experts' assessment on the impact of armed conflict on women an women's role in peace building (New York: United Nations Fund for Women. 2002.

${ }^{10}$ Williams, I. Theorizing Conflict and Violence: Contemporary Africa and the Imperatives of Peaceful Coexistence, in Africa Conflict Profile Journal of Centre for Ethnic and Conflict Studies (CENTECS), University of Port Harcourt. 2004.

${ }^{11}$ Sultan, M. From Rhetoric to Reality: Afghan Women on the Agenda for Peace: Women Waging Peace, Policy commission; hunt alternative Fund. Cambridge. Bonn talks. 2005

${ }^{12}$ Akpan F. Olofu-Adeoye, A. \& Ering, S.O. Women and Peace Building in Nigeria. African Journal of Social Sciences (4)

1 (2014) 170-182. ISSN 2045-8460 (Online) www.sachajournals.com
} 
overlooked in mainstream literature. ${ }^{13}$

\subsection{Role of Professional women in Niger Delta}

Nonetheless, there are many scholarly literature of women's peace activism in all parts of Nigeria, especially in Niger Delta region. Yomi ${ }^{14}{ }^{[14]}$ records a number of case studies of the role of women groups in post-conflict peace building and democracy in Niger Delta Region of Nigeria. They are:

1. The Escravos (Delta State) women non-violent protest in Escravos in 2002, when women occupied the tank farm that is the nerve centre of Chevron Nigeria Ltd. They held Chevron captive for ten days when angry women who were half naked, striped some Chevron men naked. All operations had to be put off while the negotiation was going on and the company was forced to declare "force majeure". The resolution entailed a signing of a Memoranda of Understanding (MOU) with the women.

2. The Ogbakiri Women, Peace Forum,

3 Niger Delta Women for Justice,

$4 \quad$ Women Without Walls Initiative (WOWWI),

5 Total Woman Foundation (TWOF).

6. Ekunuga Women's Association-Abua/Odual

Women peace builders challenge structural and cultural violence and take on marginalized issues such as access to decision-making structures, gender equality, sexual and gender-based violence, poverty and militarism. ${ }^{15,16,17}$

\subsection{Ekunuga Women's Association - Abua/Odual}

When the people of Okolomade demolished the village of Ekunuga in 1996, the women of Ekunuga intervened. They formed the Ekunuga Women's Association that comprised of women (all women including those not from Ekunuga but are married there). At the heat of the conflict about three (3) women initiated the formation of the organization and they called on the women who responded. The primary aim of the organization was for peace making and development of the community.

The women intervened in the conflict by writing the Area Commander and the District Police Officer (DPO) to assist in restoring law and order in the area.

\subsection{Ogbakiri Women's Peace Forum/Prayer Group}

Ogbakiri is a community comprising of six (6) villages in Rivers State. It is part of the Ikwerre clan. At the heat of the Ogbakiri crisis, a woman from the area called all Ogbakiri women to a meeting at the church premises that is a neutral ground on 11th May 2001. The association was formed to pray and work for peace in Ogbakiri land.

\subsection{Academic Associates Peace Works (NGO)}

The organization founded in 2000 by a sociologist who operates all over Nigeria for conflict resolution. Conflict mediation in the NDR. The focus of Academic Associates Peace works is on education. This is to empower the affected communities to resolve the conflict on their own.

\subsection{Women in Umuechem}

Umuechem is a village in Etche in Rivers State. Oil was first struck there about the end of 1950s and ever since this treasure has been flowing. Yet, there is nothing to show for it. Thus lack of development by the company and mistrust on community leaders created conflict in the community with a lot of accusations of betrayal. The women in the

\footnotetext{
${ }^{13}$ Mazurana, D. and McKay, S. Women and Peace Building. Montreal, Quebec: International Centre for Human Rights and Democratic Development. 1999.

${ }^{14}$ Yomi, O. Post-Conflict Peace Building and Democracy in an Oil Region: The Role of Women's Groups in the Niger Delta Region, Nigeria. Faculty of Environmental Sciences, Rivers State University of Science and Technology, 2015.

${ }^{15}$ Cockburn, C. From Where We Stand: War, Women's Activism and Feminist Analysis. London: Zed Books. 2007

${ }^{16}$ Best, S.G. Conflict and Peace Building in Plateau State, Ibadan, Nigeria. Spectrum Books. 2007.

${ }^{17}$ Mezie-Okoye, C. The Niger Delta Struggle in Historical Perspective. In Anikpo, M.O.C. Conflict and Development in the Niger Delta: Sociological Perspective. Enugu ABIC BOOKS. 2015.
} 
community became worried and wanted company to be aware that they were part of the problem. Though the demonstration they staged was hijacked and turned violent, the women made their point and the community was remembered and some developmental programmes have been carried out there.

\section{Ways in which Women Engage in Conflict Resolution and Peace Building}

Since the creation of the United Nations, the international perspective on women, their protection and their place in the world has been dominated by the struggle to achieve equality. Over the last twenty-five years, the international agenda has been driven by a need to create a new model of society where a culture of peace and gender equality provides the foundations. The way in which women have traditionally been seen in wars and conflicts has remained very consistent throughout history and throughout societies. Women have usually been passive subjects of war, often invisible and always victims of the conflict, compared to male combatants. Women have often played the role of

- peace mediators,

- $\quad$ trying to bring the conflict to an end;

- begging their fathers, brothers, husbands and sons to stop fighting;

- caring for children and injured war victims.

- in the midst of the horrors of war, women have had to take over the roles that society usually attributes to men, returning to their traditional roles at the end of the conflict, probably because these societies are not ready to confront the challenges of gender equality.

- Playing the role as providers, careers and social and political administrators of their communities during wartime and post-war reconstruction

- caring for surviving male combatants,

Yet women do not receive the same care, either for their health or their rights. Thus for post-war reconstruction to result in lasting peace, women should receive special attention and be fully incorporated into the peace process.

\section{Challenges Women Face in Playing Their Role in Conflict Resolution and Peace Building}

1. Women themselves are not ready to champion their own course

2. Lack of cooperation from men for fear of women leadership

3. Negative societal perception of the role of women

4. Lack of awareness of benefits of gender equality

5. Lack of awareness of gender issues

6. Lack of policy to back women involvement in conflict resolution and peace building

\section{Strategies for Involving Women as Established by UN}

The strategy of the United Nations has therefore focused on working with women for peace, and on developing a gender perspective in establishing peace.

Utilizing women's capacity for leadership to the full and to the benefit of all, in order to progress towards a culture of peace.

Women should be allowed to participate in governance at all levels, for this in order to achieve the United Nation's agenda on gender equality. Women are key source of creativity, idea- oriented, innovative in such areas as conflict prevention, the promotion of cross-cultural dialogue and the redressing of socio-economic injustice. The knowledge of women in family management skills has given them insights essential to peaceful human behavior and social development.

Women are fable to violence and can bring a new breadth of life, quality vision towards integrating culture to peace building in the society.

Several International conferences are held in deferent parts of parts of the world today on gender equality such as Mexico (1975), Copenhagen (1980), Nairobi (1985), Beijing (2000) and New York (2000 and 2005). These action plans have developed from the earliest versions that considered women in terms of their development needs, to now recognize the fundamental and essential contribution they can make to the whole development process, empowering their roles and promoting their right to participate fully at all levels of human activity. 


\section{Conclusion}

Just a few weeks ago the world celebrated the 2016 Day of Women with a theme: "Creating awareness on gender equality and women empowerment for development". This shows that many people are still ignorant of gender issues and its implication in conflict resolution and peace building. A professional body in Nigeria, the International Federation of Women Lawyers (FIDA) held a radio talk show where they advocated that gender parity should start from home and schools and then society at large. Time has come for everybody to be aware of gender equality and participation in conflict resolution and peace building. This is the only way the world can be safe, peaceful and enjoyable.

\section{Suggestions for Improving the Role of Professional Women in Conflict Resolution and Peace Building}

1. Awareness needs to be intensified among professional women so that women generally will be aware of gender equality and participation in conflict resolution and peace building

2. Women should be integrated in peace building issues

3. Mothers should teach their children skills in anger management as anger is a little madness. What anger will cause will always be more than what caused the anger.

4. Women should also be committed to peace in their homes as prevention is better than cure. A peaceful home leads to a peaceful town which leads to a peaceful state and a peaceful nation.

\section{References}

Akpan, F., Olofu-Adeoye, A., \& Ering, S. O. (2014). Women and peace building in Nigeria. African Journal of Social Sciences, 4(1), 170-182.

Albert, O. (1996). Women and Urban Violence in Kano, Nigeria. Ibadan: Spectrum Books Limited.

Anikpo, M. O. C. (1996). The dynamics of socio-cultural change in Nigeria's oil prodicing communities: The case of Izombe Energy and social Development in Nigeria. Onyige, P.U. Longman.

Anikpo, M. O. C. (2015). Conflict and Development in the Niger Delta: Sociological Perspective. Enugu: ABIC BOOKS

Bakky, N. A. (2014). Women in Peace Education. IOSR Journal of Research \& Method in Education (IOSR-JRME), 4(3) 01-08.

Best, S. G. (2007) Conflict and Peace Building in Plateau State, Ibadan,Nigeria, Spectrum Books.

Boulden, J. (2004). Dealing with conflicts in Africa: The United Nations and Regional Organizations. Basingstoke: Macmillan Publishers

Cockburn, C. (2007). From Where We Stand: War,Women's Activism and Feminist Analysis.London: Zed Books.

Collenris, R. (1975). Conflict Sociology: Towards an Explanatory Science. New York and London: Academic Press.

Coser, L. A. (1956). The Functions of Social Conflict. Gluncoe III. The Free Press.

Faleti, S. (n.d.). (2006). Theories of social conflicts in Shedrack, G. B. : Introduction to Peace and Conflicts studies in West Africa. Ibadan: Spectrum Books.

International Alert. (1999). Women, Violent Conflict and Peace building: Global Perspectives. International Conference Report. London.

Kemedi, D. V., Alagoa, N. C., \& Leton, M. (2015) Oil Politics and Communual Conflicts in Niger Delta: A Traditional approach to prevention, management and resolution.

Mazurana, D., \& McKay, S. (1999). Women and Peace building Montreal, Quebec: International Centre for Human Rights and Democratic Development.

Mezie-Okoye, C. C. (2015). The Niger Delta Struggle in Historical Perspective. In Anikpo, M. O. C. (2015). Conflict and Development in the Niger Delta: Sociological Perspective. Enugu: ABIC BOOKS.

Oshita, O. O., Ikelegbe, A.W., \& Golwa, J. H. P. (2015). Case Studies of Traditional Methods of Conflict Prevention and Resolution in Nigeria.

Rhen, E., \& Sirleaf, J. (2002). Women, war and Peace; the independent expert's assessment on the impact of armed conflict on women and women's role in Peace Building (New York: United Nations Fund for Women, 2002)

Sultan, M. (2005). From Rhetoric to Reality: Afghan women on the agenda for peace: Women waging peace, policy commission; hunt alternative fund, (Cambridge: Bonn talks, 2005).

The foundation coalition; Understanding Conflict and Conflict Management. (2015). Retrieved from 
http://www.foundationcoalition.org/teams on January 8th, 2015.

Williams, I. (2004). TheorizingConflict and Violence: Contemporary Africa and The Imparative of Peaceful Coexistence, in African Conflict Profile-Journal of Center for Ethnic and Conflict Studies (CENTECS), University of Port Harcourt.

Yomi, O. (2015). Post-Conflict Peace Building and Democracy in an Oil Region: The Role of Women's Groups in the Niger Delta Region, Nigeria. Faculty of Environmental Sciences, Rivers State University of Science and Technology.

\section{Copyrights}

Copyright for this article is retained by the author(s), with first publication rights granted to the journal.

This is an open-access article distributed under the terms and conditions of the Creative Commons Attribution license which permits unrestricted use, distribution, and reproduction in any medium, provided the original work is properly cited. 